\title{
Idősek városképe - egy városmárka-asszociációs kutatás korcsoportspecifikus eredményei
}

\author{
Elderly cityscape - Age-specific results of a city brand \\ association research
}

\section{KOVÁCS LÁSZLÓ, ZSARNÓCZKY MARTIN, KELLER KRISZTINA, TÓTH-KASZÁS NIKOLETTA}

KOVÁCS László: egyetemi docens, Eötvös Loránd Tudományegyetem, Társadalomtudományi Kar, Savaria Gazdálkodástudományi Tanszék; 9700 Szombathely, Károlyi Gáspár tér 4.; kovacs.laszlo@sek.elte.hu; https://orcid.org/0000-0003-0641-811X

ZSARNóCZKY Martin: egyetemi docens, Kodolányi János Egyetem; 1139 Budapest, Frangepán utca 30-36.; martin@kodolanyi.hu; https://orcid.org/0000-0002-2905-2168

KELLER Krisztina: egyetemi docens, Budapesti Corvinus Egyetem; 1093 Budapest, Fővám tér 8.; krisztina.keller@uni-corvinus.hu; https://orcid.org/0000-0002-4408-7940 TÓTH-KASZÁS Nikoletta: egyetemi adjunktus, Pannon Egyetem, Nagykanizsai Kampusz; 8800 Nagykanizsa, Zrínyi u. 18.; kaszas.nikoletta@uni-pen.hu; https://orcid.org/ 0000-0001-5147-2022

KULCSSZAVAK: településmárka; városmárka; asszociáció; idősek

ABSZTRAKT: A települési kutatások aktuális területét képezik a márkázással kapcsolatos elemzések, melyek a településeket - településmárka címszó alatt - a márkamenedzsment szemszögéből vizsgálják. Bár összefoglaló néven településmárkáról beszélhetünk, ez a legtöbb esetben városok márkázását jelenti. Jelen kutatásban a településmárkából, mint az elmében létrejövő entitásból indulunk ki. Ezzel Aaker (1991) és Keller (1998) mellett Sebastian Zenker városmárkákkal kapcsolatos kutatásai jelentik a vizsgálat kiindulópontját - elsősorban a Zenker és Braun (2017) által megalkotott modell, amely a település márkáját a tudatunkban a településhez kapcsolódó asszociációkként értelmezi.

Kutatásunkban egy városmárka és a „fogyasztó” kapcsolatát asszociációs módszerrel vizsgáltuk meg: a lakosoknak a városmárka nevéhez kötődő asszociációit elemeztük. A vizsgálat tárgya Nagykanizsa, a vizsgálat alanya pedig egy konkrét csoport, a Nagykanizsán élő idős generáció.

Az asszociációk alapján kirajzolódó aktuális kép megmutatja, hogy milyen jellemzők nehezítik és / vagy könnyítik meg az idősek mindennapjait a városban. Az eredmények alapján jellemezzük az idősek várossal kapcsolatos képét, majd rámutatunk arra, hogy az idős generáció tagjai amellett, hogy a város egy korábbi, általuk ismert képét hívják elő, a következő generációk szükségleteit is szem előtt tartják. A gyüjtött asszociációk alapján Zenker és Braun (2017) településasszociációkkal kapcsolatos modelljét is módosítjuk. A tanulmány végén javaslatokat fogalmazunk meg, amelyek felhasználásával Nagykanizsa idős lakossága jobban integrálhatóvá válhat a város mindennapjaiba.

László KoVÁCS: associate professor, Savaria Department of Business Administration, Faculty of Social Sciences, Eötvös Loránd University; Károlyi Gáspár tér 4., H-9700 Szombathely, Hungary; kovacs.laszlo@sek.elte.hu; https://orcid.org/0000-0003-0641-811X

Martin ZSARNÓCZKY: associate professor, Kodolányi János University; Frangepán utca 30-36., H-1139 Budapest, Hungary; martin@kodolanyi.hu; https://orcid.org/0000-0002-2905-2168

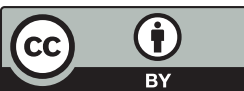


Krisztina KELLER: associate professor, Corvinus University of Budapest; Fövám tér 8., H-1093 Budapest, Hungary; krisztina.keller@uni-corvinus.hu; https://orcid.org/0000-0002-4408-7940 Nikoletta TÓTH-KASZÁS: assistant professor, Nagykanizsa Campus, University of Pannonia; Zrínyi u. 18., H-8800 Nagykanizsa, Hungary; kaszas.nikoletta@uni-pen.hu; https://orcid.org/ 0000-0001-5147-2022

KEYWORDS: place branding; city branding; associations; elderly inhabitants

One of current areas of research on settlements and places is place branding, in which settlements are examined from the perspective of brand management. Although often the more general term "place branding" is used, the branding of places means in most cases city branding. Collecting and analyzing city brand associations is a relatively new research area within city brand research.

This paper considers brands and place brands as entities formed in the mind. The theoretical framework of the study is based on Aaker (1991) and Keller (1998) and especially on Sebastian Zenker's city brand models. As a starting point the model of Zenker and Braun (2017) is discussed that interprets place brands as associations connected to a place in the mind of the consumer.

In the study, the relationship between a city brand and the consumer of the brand is analyzed with associations. The city analyzed in the study is Nagykanizsa, a middle-sized city in southwestern Hungary and the "consumer" is the elderly generation living in Nagykanizsa. The paper collects associations from elderly inhabitants of the city, thus narrowing down the research to a specific age group.

Associations to the city are collected in several contexts: 1) free associations, 2) associations describing why elderly are proud of the city, 3) associations to things elderly are satisfied with, and 4) dissatisfied with in Nagykanizsa.

The current picture, drawn from the associations shows which features of the city make the daily life of elderly people in the city difficult and / or easy. Based on the results the city image of the elderly inhabitants is described, showing that tourist attractions and the city's infrastructure make inhabitants proud. They are however dissatisfied with the traffic infrastructure of the city, especially the condition of the sidewalks. Bus traffic in the city is regarded both as satisfactory and dissatisfactory, depending on the area people live in and the directions they travel. The study also points out, that members of the older generation, in addition to evoking an earlier image of the city, also consider the needs of future generations, especially the lack of workplaces. Based on the collected associations Zenker and Braun's (2017) model is modified.

In the last part of the study, suggestions are made to help to integrate the elderly inhabitants of the city more into city life. It is suggested that the livability of the city can be improved and mobility issues are important for elderly people. At the end of the paper limitations of the research are described and new research directions are pointed out.

\section{Bevezetés}

A településvizsgálatok egyik sajátos területe márkaként tekint a településekre: azt kutatja, hogy mi jellemzi a településmárkákat, illetve a márkázás mely eszközei és módszerei, milyen kontextusban vihetők át a településekre (Dinnie 2011; Piskóti 2012). Nemcsak leírja egy márka jellemzőit, de egyben azt is megmutatja, hogy a településmárka mely összetevőinek hangsúlyozása lehet hatékony a település vonzóvá tételében (Vanolo 2017). Bár általában településmárkáról beszélünk, a legtöbb esetben ez városok márkázását jelenti, és a témakörben megjelenő publikációk is a városok márkázási jellemzőit vizsgálják. 
A városmárkára legalább háromféle megközelítésben tekinthetünk:

- lakóhelyként, amelynek elsődleges célja lakosság vonzása és megtartása;

- különböző vállalkozások telephelyeként, amelynek célja vállalkozások (munkahelyek és bevételek) vonzása és megtartása;

- desztinációként, amelynek célja turisták vonzása, illetve ösztönzése arra, hogy minél több időt töltsenek el a városban, és / vagy minél gyakrabban látogassanak a településre (Kotler et al. 1993; Zenker et al. 2017).

A háromféle megközelítés nem különíthető el szigorúan egymástól: a vállalatok megtelepedése lakosságot vonz(hat), míg a turisztikai látnivalók nem csak a turisták élményeit gazdagítják; a turisták ugyanakkor a lakosság mindennapjaira is pozitív vagy negatív hatással vannak, például a megnövekedett forgalom révén (Hanna, Rowley 2015; Insch 2011; Zenker et al. 2017). A város desztinációként történő értékelésére erősen hathat a desztináció személyiségének megítélése - azaz, hogy milyen személyiségjegyek társíthatóak egy desztinációhoz (Gyulavári, Malota 2019). Városok esetében így izgalmas kérdés, hogy azok személyisége mennyire egyezik az adott személy saját magáról alkotott képével.

Tanulmányunk a várost annak lakói szemszögéből elemzi. A lakóhely városmárka képe nagyban összefügg a lakók elégedettségével (Insch 2011; Rößler 2019). Zenker, Petersen és Aholt (2013) a lakók elégedettségét négyféle megközelítésben: (1) urbanitás és sokszínűség, (2) természeti és rekreációs lehetőségek, (3) munkalehetőségek és (4) költségek mentén ragadják meg, rámutatva arra, hogy a négy tényező közül az első kettő jobban befolyásolja az elégedettséget.

Vizsgálatunkban a településmárka emberek tudatában elfoglalt helyéből indulunk ki: rámutatunk arra, hogy a településsel kapcsolatos asszociációk hogyan befolyásolják az attitüdöt és a viselkedést. A kutatás empirikus elemzésre támaszkodik: egy nyugat-magyarországi város, Nagykanizsa idős lakosai körében végzett, városmárkára vonatkozó kutatás keretében gyűjtött asszociációkat mutatjuk be, kategorizáljuk, majd értékeljük. Az adatok elemzése után egyrészt bemutatjuk, hogy az eredmények alapján hogyan módosítható a városmárkaasszociációk elméleti keretrendszere, másrészt gyakorlati javaslatokat fogalmazunk meg arra vonatkozóan, hogy miként lehetne a város még inkább idősbarát település.

\section{Településmárka az elmében}

Jelen kutatás a városra lakóhelyként tekint, ezért kiemelt szerepet kap benne az identitás kérdése. A kutatásban Piskóti (2012) kétirányú identitásfogalmából indulunk ki, mely szerint az identitás értelmezhető egyrészt a városról egyes személyek - lakosok és nem lakosok - elméjében élő képként, amelynek funkciója az adott város megkülönböztetése, másrészt felfogható a lakosok várossal való azonosulásaként, azaz a kötődés és összetartozás érzéseként. 
A várossal való azonosulásnak nem feltétele, hogy a település lakosa a város szülötte legyen; sőt az is elképzelhető, hogy a lakos más ország állampolgára, aki az adott ország (jelenlegi lakóhelye) nyelvét nem is beszéli (Namaz et al. 2018). Azonban az identitás, a csoporthoz kötődés tudatos építése és erősítése elengedhetetlen ahhoz, hogy a város szülöttei hosszú távon (életük végéig) szülővárosukban képzeljék el a mindennapjaikat (Birkner 2017).

Általánosan elfogadott megállapítás, hogy a márka a fogyasztó tudatában születik, Keller $(1998,10$.) megfogalmazásában: „a brand is something that resides in the minds of consumers". Település- és városmárka esetében is beszélhetünk annak tudatunkban elfoglalt helyéről, azaz arról a képről, amely bennünk a településmárkáról él (Zenker, Braun 2010).

Megkülönböztethetjük egymástól a településmárka kézzel fogható jellemzőit (például a város fizikai képét a szimbolikus épületekkel vagy a város címerét), és mindezen jellemzők kognitív reprezentációját, vagyis azokat az asszociációs struktúrákat, amelyeket az egyes fogyasztók a településsel kapcsolatban tudati síkon kialakítanak. A különbségtétel azért releváns, mert a városmárka külső jellemzőit, illetve annak látható változásait - egy új beruházás vagy egy új címer nyomán - az egyének különbözőképpen ítélik meg. Míg egy négysávos út a rajta közlekedő, a város távoli részén lakónak pozitív és kívánatos beruházás, addig azok körében, akiknek ingatlana közelében az út elhalad, a beruházás inkább negatív megítélésű lesz a megnövekedett zaj- és környezeti terhelés miatt. Tehát ugyanazon jellemző - így a példánkban szereplő új út - értékelése különböző célcsoportokban eltérő lehet.

A városmárka tudatunkban elfoglalt helyét asszociációkon keresztül vizsgálhatjuk. Aaker megközelítésében márkaasszociáció minden olyan képzettársítás, ami a márka nevéhez kötődően tudatunkban kialakul: „[a] brand association is anything „linked” in memory to a brand” (Aaker 1991, 109.). Az ő gondolatmenetét folytatva, Keller a márkaasszociációk jelentésalkotó szerepére hívja fel a figyelmet: „Brand associations are the other informational nodes linked to the brand node in memory and contain the meaning of the brand for consumers" (Keller 1998, 93.). A magyar nyelvű szakirodalomban általános megfogalmazásokat olvashatunk a márkaasszociációkkal kapcsolatban. Rekettye és Hetesi szerint a „márkaasszociáció a márkával kapcsolatban a vásárlók, fogyasztók, vevők, ügyfelek, partnerek fejében létrejött gondolatok és érzelmek" (Rekettye, Hetesi 2009, 81.), míg Bauer és Berács a márkaasszociációkat mint „a fogyasztóknak a márkához fűződő érzéseit és gondolatait" definiálja (Bauer, Berács 2006, 174.; részletesen lásd Kovács 2017).

Kutatásunkban a márkaasszociációk eszközét településekre alkalmazzuk. Ötvözzük Zenker és Braun (2010) koncepcióját, amely a településmárkákat a fogyasztók tudatában létező asszociációs hálózatként értelmezi, illetve Kovács (2017) kognitív márkareprezentációs fogalmát. Ezzel a településmárka tudati szerepét hangsúlyozzuk, és annak kognitív reprezentációjáról beszélünk. „A telepü- 
lésmárka kognitív reprezentációján a településmárka egyes fogyasztók elméjében elfoglalt helyét értjük, azokat az asszociációkat, konnotációkat, képeket, illatokat, érzéseket és egyéb érzékszervi benyomásokat és emlékeket, valamint attitüdöket, értékeket és jellemzőket, amelyeket a településmárka, vagy annak valamely eleme előhív elménkből, illetve amelyekkel az kapcsolatban van" (Kovács et al. 2020, 19.).

A településmárka létrehozói megközelítésünkben tehát azok az asszociációk, amelyek tudatunkban a településhez kapcsolódnak. Az asszociációk nemcsak szavak lehetnek, hanem minden olyan multiszenzoros élmény, amelyet előhívunk elménkből a település nevét hallva (Kovács et al. 2020). A kutatásunkban elvégzett vizsgálatok során az asszociációkat írásban kértük, így az előhívott asszociációk szavakban kifejezett formáját tudtuk vizsgálni.

A településmárkához kapcsolódó asszociációk sokfélék lehetnek. Zenker, Braun és Petersen (2017) arra hívják fel a figyelmet, hogy ezek az asszociációk tartalmazhatnak - a település (karakterisztikus) épületeivel, történetével vagy elhelyezkedésével kapcsolatos asszociációk mellett - értékelést is, például a településre vonatkozó jelzők formájában. Ugyanakkor nagyon különböző lehet a településmárka megítélése, ha azt a lakosok és a nem lakosok (például turisták) körében vizsgáljuk. Míg előbbiek a település változásait is megélik, illetve a település jó és rossz oldalával egyaránt találkoznak, addig utóbbiak csak a település egy - általában jó és szép - oldalát látják, és a települést ezen nem teljes, sokszor felületes benyomás alapján értékelik. Egy település megítélése lakóhelyként és desztinációként a különböző célcsoportok körében így nagyon különböző lehet (Egresi 2018).

A településekkel kapcsolatos asszociációk, valamint az asszociációkból alkotható hálózatok tehát célcsoportspecifikus jellemzőket mutatnak: Zenker és Beckmann (2013) például hamburgi kutatásaiban a megkérdezett célcsoportok szerint mutatta be a város márkájának különböző asszociációs hálózatait. A különböző célcsoportok eltérő percepcióját mutatja az 1. ábrán látható modell (Zenker, Braun 2017).

A modell a településmárka percepcióját az elmében létrejövő asszociációs kapcsolatokból álló hálózattal írja le, és felhívja a figyelmet arra, hogy a kommunikáció, a célcsoport, illetve a kommunikáció célcsoportra gyakorolt hatása függvényében az egyes célcsoportokat más-más attitüd jellemezheti, illetve viselkedésük is különböző lehet. Dörnyei, Csordás és Gáti (2013) rámutat arra, hogy a sikeres kommunikáció nagyban függ az információkeresési tevékenység technológiai hátterétől, így a településről a célcsoport számára közvetített információ befogadása erőteljesen függ a közvetítő közeg (média) tulajdonságaitól.

A következőkben egy kérdőíves kutatásban a fenti modellt egy speciális célcsoportra, egy magyarországi középváros - Nagykanizsa - időskorú lakosaira alkalmazzuk. A kutatásban a célcsoporttól gyűjtött szabad és irányított asszociációkat elemezzük, majd megvizsgáljuk, hogy Zenker és Braun fenti modelljét hogyan alkalmazhatjuk a célcsoport esetében. 
1. ábra: Településmárkák percepciója Zenker és Braun modellje szerint

The concept of place brand perception according to Zenker and Braun
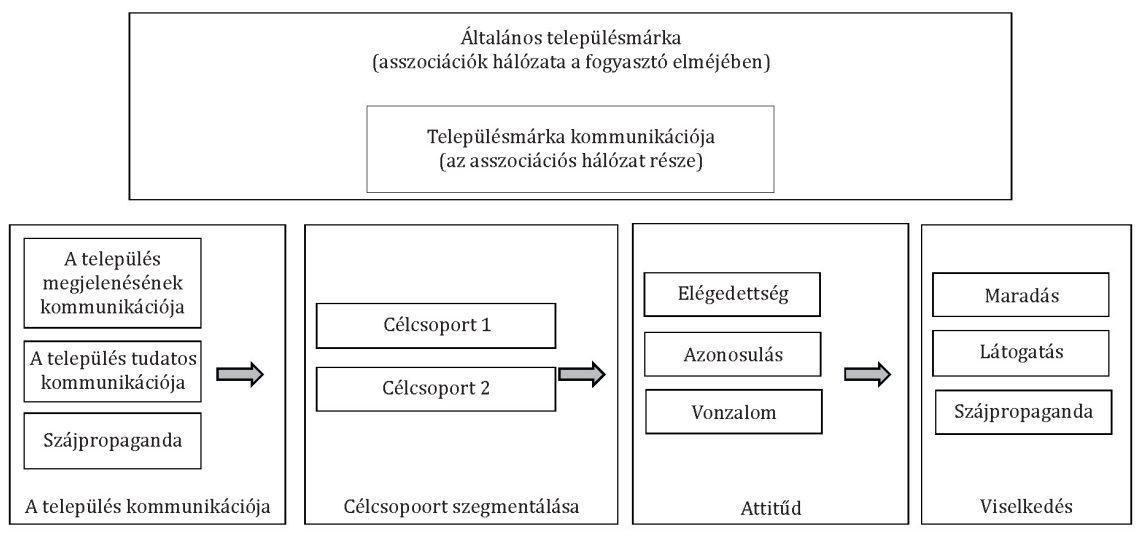

Forrás: Zenker és Braun $(2017,277$.

A hazai időskorúak körében több olyan kutatás is készült 2016-2017 folyamán, amelyekben Zsarnóczky elsődlegesen a fogyasztással kapcsolatos döntési mechanizmusokat és preferencia-impulzusokat vizsgálta az észak-magyarországi, valamint a dél-dunántúli régióban. E turizmusfogyasztáshoz kapcsolódó vizsgálatok eredményei rámutattak arra, hogy egyrészt az időskorúak nem tekinthetők egyetlen homogén csoportnak, másrészt hogy a lakókörnyezet földrajzi eltérései szerepet játszhatnak fogyasztási döntéseik meghozatalában (Zsarnóczky 2017, 2018).

A nemzetközi szakirodalom (Depping, Freund 2011; Drolet et al. 2011; Hess et al. 2015) a 2000-es évek első évtizedéig intenzíven kutatta az időskorúak döntéseiben szerepet játszó tényezőket. Ezekben a vizsgálatokban a 65 év felettiek egységes demográfiai csoportot alkottak, mely megközelítés eltér a későbbi, differenciált szemléletmódot alkalmazó hazai vizsgálatoktól. Az egy halmazra fókuszáló mintavételek helyett ugyanis ma már longitudinális módszerrel, kohorsz alapú demográfiai bontásban vizsgálják az időskorúak csoportjait. Kiemelt szerepe van a fizikai, a kognitív és az érzelmi fejlődés meghatározhatóságának, amelyek mellett az egészség, a jóllét és az egyéni teljesítmény is fontos jellemzők. A kohorsz csoportok esetében például olyan társadalmi háttértényezők, mint a családi és társas környezet, vagy a szociológiai különbségek együttesen vizsgálandók. Az egymással kölcsönhatásban lévő tényezők eltérései jól rámutathatnak az egyes kohorsz csoportokra jellemző hatásmechanizmusokra.

\section{Anyag és módszer}

Nagykanizsa Magyarország délnyugati kapuja, dinamikusan fejlődő megyei jogú város, a nyugat-dunántúli régió legdélebbi városa (Nagykanizsa honlapja 2019). 
Fekvésének köszönhetően a térség gazdasági, foglalkoztatási és szolgáltatási központja. Számos település tartozik a vonzáskörzetébe, melyek mindegyike több területen (pl. oktatás, munkalehetőségek, egészségügy, hivatali ügyintézés, kereskedelem) függ a várostól (M7 Projektcsoport Pannon Egyetem Nagykanizsa 2009). Nagykanizsa Zala megye második legnagyobb városa, lakossága 2018. január 1-jén 47337 fö volt. A 2015. évi népességadatokhoz képest ezer fővel csökkent a lakosság száma (Településstatisztikai adatok 2019). 2018-ban a város népességének mindössze 12\%-a volt 0-14 év közötti, míg 20\%-a 65 éves, vagy annál idősebb. A lakónépességen belül a munkaerőpiaci szempontból aktívnak számító lakosság aránya is csökkenést mutat: 2010-ben 61,4 \% volt, 2018-ban már csak 57,6\% (Nagykanizsa honlapja 2019; Városfejlesztés Zrt. 2014).

Az idős korosztály aránya évről évre nő Nagykanizsán, így az önkormányzat fontosnak tartja támogatásukat, illetve bevonásukat a város életébe. A település személyes gondoskodást nyújtó szociális ellátórendszere jó színvonalú: a szolgáltatások között az étkeztetés, a házi segítségnyújtás, az idősek otthona és a támogató szolgáltatás is megtalálható. Az idős lakosság helyzetének javítását szolgálják az önkormányzat által biztosított pénzbeli és természetbeni ellátások is: ilyen például a lakásfenntartási támogatás, az eseti gyógyszertámogatás és az egészségügyi szolgáltatásokra való jogosultság (Nagykanizsa Megyei Jogú Város Önkormányzatának Idősügyi Koncepciója 2012).

Az önkormányzat évek óta hozzájárul ahhoz, hogy a Nagykanizsán élő idösek aktívan, közösségben tudják eltölteni mindennapjaikat. A városban és vonzáskörzetében 30 idősek klubja működik, melyek mindegyike számos programmal várja tagjait (Idősügyi Tanács honlapja 2019). Az önkormányzat a kluboknak a városban található közművelődési intézményekben térítésmentesen biztosít teret és szakmai támogatást. Az önkormányzat által meghirdetett pályázatok pedig segítséget nyújtanak a klubok által megvalósított események megszervezéséhez. Emellett számos további szervezet biztosít rendezvényeket a Nagykanizsán élő idősek és idősklubok számára. A Nagykanizsai Egyesített Szociális Intézmény szervezésében 1994 óta minden évben megrendezésre kerül az Idősek Hete programsorozat, 2003 óta pedig az Idősek Világnapjához kapcsolódóan az Idősekért Nagykanizsán Ünnepi Hét. Ezek az események ráirányítják a figyelmet a városban élő idős lakosság tiszteletére, illetve lehetőséget nyújt nekik tudásuk, tenni akarásuk és értékeik bemutatására. A Halis István Városi Könyvtár számítógép- és internethasználatot biztosít a város időskorú lakosságának (Nagykanizsa Megyei Jogú Város Önkormányzatának Idősügyi Koncepciója 2012).

Empirikus vizsgálatunkban 2018 októbere és 2019 márciusa között a város 28 idősek klubjának tagjait kérdeztük meg kérdőíves kutatás keretében. Kutatásunk célja az volt, hogy megismerjük a válaszadók Nagykanizsáról alkotott véleményét, településsel kapcsolatos asszociációit, szabadidejük eltöltésének módját. A felméréssel Nagykanizsa önkormányzatának munkáját is segíteni kívántuk, ezért eredményeinket átadtuk a polgármesternek. 
A kutatás ötletével az Idősügyi Tanácsot kerestük meg, melynek támogatásával a klubok vezetői segítették a lekérdezést. Alapsokaságnak a nagykanizsai idősklubok taglétszámát tekintettük: ez a vizsgálat idején 1442 fö volt. A mintavétel során a véletlen kiválasztás elvét alkalmaztuk. A kapott eredmények a klubok tagságának számára vonatkozóan reprezentatívak. A kérdőíveket a válaszadók a klubtalálkozókon töltötték ki. 504 értékelhető kérdőívet kaptunk, amely az alapsokaság közel 35\%-a: 365 nő és 139 férfi adott választ a kérdéseinkre. Mivel az idősklubok tagjai lehetnek korkedvezményes nyugdíjba vonulók, rokkantnyugdíjasok és a közszféra szolgálati idejüket letöltő alkalmazottai is, a kérdőív kitöltői között vannak 50-60 év közöttiek is (1. táblázat). A megkérdezettek életkorát - az Idősügyi Tanács vezetőjének ismeretei és tapasztalatai alapján - nominális skálán, 52 éves kortól a 85 év feletti kategóriáig mértük. A válaszopciókat egyenlő kategóriákra osztottuk.

A megcélzott generáció sajátosságainak megfelelően állítottuk össze a kérdéssort, de ügyeltünk arra, hogy legyenek olyan kérdések is, amelyek segítségével összehasonlító vizsgálatokat tudunk végezni. A kérdőíves felmérés alkalmas leíró, magyarázó és felderítő kutatási célokra is. Egyik célunk az asszociációk feltárása volt, így a kérdőíves megkérdezés előnyösnek bizonyult, hiszen a válaszadóknak volt ideje végiggondolni a több időt igénylő, elgondolkodtató kérdéseket is. A kérdőívek alkalmazásával továbbá el kívántuk kerülni azt, hogy a válaszadók befolyásolják egymás véleményét. A nyugdíjasok a kérdőíveket papíron, önkitöltős módszerrel töltötték ki, a kapott válaszokat Excel-táblázatban rögzítettük. A válaszadók korösszetétele az 1. táblázatban látható.

1. táblázat: A válaszadók korösszetétele

Age distribution of the respondents

\begin{tabular}{cc} 
Korcsoport & Adatkozlo (†o) \\
\hline 52-62 év között & 56 \\
63-73 év között & 279 \\
74-84 év között & 147 \\
85 éves vagy idősebb & 17 \\
Nincs válasz & 5 \\
\hline
\end{tabular}

Forrás: Saját szerkesztés

\section{Asszociációs módszer}

Az asszociációs technikák a kvalitatív módszerekhez sorolhatók (Aaker et al. 2001) és projektív technikáknak minősülnek (Franzen, Bouwman 2001; Gyulavári et al. 2014; Malhotra, Simon 2007). Aaker (1991) ezen felül az indirekt módszerekhez sorolja az eszközt.

Az asszociációs módszereknek nagyon sok fajtája létezik: beszélhetünk például szabad, irányított és korlátozott asszociációkról, asszociációk kereséséről, de 
lehet asszociációkat Likert-skálán besorolni, illetve rajzoltathatunk asszociációkból mentális térképeket (Aaker 1991; Kovács 2017). Ezek közül kutatásunkban a következőket alkalmaztuk (Kovács et al. 2020):

- Szabad asszociációk: arra kérjük az alanyt, hogy írja le vagy mondja ki, mi jut eszébe, ha a márka nevét hallja. Fontos, hogy az első szót nevezze meg, ne gondolkodjon a válaszon. „Kérjük, soroljon fel három dolgot, ami Nagykanizsáról először az eszébe jut!'

- Irányított (kontrollált) asszociációk: a feladatban arra kérjük az alanyt, hogy az előhívott asszociációit valamilyen előre meghatározott kritériumnak megfelelve adja meg.,,Kérjük, soroljon fel három dolgot, amelyre büszke Nagykanizsán!”,Kérjük, írja le, hogy mivel elégedett Nagykanizsán!” „Kérjük, fogalmazza meg, hogy mivel nem elégedett Nagykanizsán!"

Az asszociációk elemzésének első lépése a kategorizálás (Kovács et al. 2020), ami azért fontos, mert esetenként több száz - jelen kutatásban a szabad asszociációknál 1050 db - egyedi asszociáció elemzése nehezen kivitelezhető. Az asszociációs kutatások kategóriákba csoportosítják a lehetséges, illetve gyűjtött asszociációkat, hogy így tegyék lehetővé az elemzést (Aaker 1991; Franzen, Bouwman 2001; Kovács 2017). Az asszociációk kategorizálására számos megoldás létezik. A településmárkák asszociációi kapcsán a paritásos és a differenciáló elemeket különíti el Piskóti (2012, 318-319.), ahol paritásos elemeken olyan, nem egyedi asszociációkat ért, amelyek nem csak egy márkát jellemezhetnek. A másik csoport a differenciáló elemek köre, amely az egyértelműen egy márkához rendelhető, erős, kedvező, egyedi asszociációkat tartalmazza. Ez a kettősség más szerzőknél is megjelenik: Zenker (2011) például általános (common), illetve egyedi (unique) asszociációknak nevezi a két kategóriát. Az általunk gyüjtött adatok között is megfigyelhető e kettősség: az asszociációk egy része egy településkategóriára általánosan jellemző (például múzeumok, fesztiválok), míg mások egyértelmüen csak a várossal és környékével azonosíthatók (Miklósfai parkerdö, Város Napja).

Asszociációs kutatások esetén a válaszok kategorizálása gyakran nem előzetesen felállított szempontok szerint, hanem utólag történik meg (Kastens 2009; Kovács 2017). Kastens (2009) például a BMW felhasználókkal kapcsolatos asszociációkat elemezve úgy látta, hogy Aaker (1991) „felhasználó, vásárló” kategóriája nem differenciál eléggé, ezért külön kérdésben kérdezett rá a BMW felhasználó jellemzőire („Mely tulajdonságok jellemzik a tipikus BMW tulajdonost?”). Ezt követően a válaszokat (a tipikus tulajdonos jellemzőit) kategorizálta tovább, többek között nem, életkor, társadalmi státusz, sztereotípiák, foglalkozások, származás és családi állapot szerint.

Kutatásunkban hasonlóan jártunk el az asszociációk besorolásakor: a kategóriákat utólag, az asszociációk ismeretében alkottuk meg, ahol a szabad asszociációk kategorizálásához Kovács (2017) módszertanát vettük alapul. A kategorizálásba bevontuk az egyes kategóriák általános és egyedi (a felosztásban általános 
és specifikus) dimenzióit is, így Piskóti (2012) differenciáló és paritásos kategóriái is vizsgálhatók (Kovács et al. 2020). A megalkotott kategóriák a szabad asszociációk esetében a következők:

- látványosság általános

- látványosság specifikus

(szökőkút)

- szolgáltatás általános

- szolgáltatás specifikus

- bevásárlás / bolt általános

- bevásárlás / bolt specifikus

(Erzsébet tér)

(vendéglátó egységek)

(McDonald's)

(ruházati üzletek)

- szórakozás / szabadidő általános

(Spar)

- szórakozás / szabadidő specifikus

(sport, edzés)

- infrastruktúra általános

- infrastruktúra specifikus

- személyek általános

- személyek specifikus

- kategorizálás

- jelző / jellemző

- foglalkoztatás / cég általános

- foglalkoztatás / cég specifikus

(Kanizsa Fest)

(kellemes helyek)

(Sugár utca)

(sok lezüllött fiatal)

(Nagy Feró)

(város)

(unalmas/unalom)

(kevés munkalehetőség)

(Scania szerviz)

- település része

- attitűd

- városmárka jellemzője

- politika

- nem besorolható

(Citromsziget)

(szeretem ezt a várost)

(város címere)

(nem jó vezetőség)

(árvácska)

Az irányított asszociációk kategóriái ettől részben eltérnek (lásd alább). A szabad asszociáció, illetve a „mire büszke” asszociációk kategóriáit ezért úgy alkottuk meg, hogy azok ne csak az idősekkel kapcsolatos adatfelvétel asszociációit írják le, hanem más korcsoportok asszociációs struktúráit is, ezáltal az egyes korcsoportok struktúrái egymással összevethetők legyenek (Kovács et al. 2020). Hasonlóan cselekedtünk a „mivel elégedett / mivel elégedetlen” kérdésekre adott asszociációk kategorizálásánál.

\section{Eredmények}

A felmérés keretében gyüjtöttünk 1050 db szabad asszociációt, továbbá 1151 db irányított asszociációt a büszkeséget, 557 db irányított asszociációt az elégedettséget, valamint $707 \mathrm{db}$ irányított asszociációt az elégedetlenséget firtató kérdésekre. Az adatok egy része ugyanakkor értékelhetetlennek bizonyult. Ezek a válaszok nem állnak kapcsolatban a felvetett témával, így azokat egyetlen kategóriába sem soroltuk be. 


\section{Szabad asszociációk}

Első lépésben a kutatás során gyüjtött szabad asszociációkat („Kérjük, soroljon fel három dolgot, ami Nagykanizsáról először az eszébe jut!”) elemeztük. Az előhívott asszociációkat egyenrangúnak tekintettük, azaz nem kategorizáltuk aszerint, hogy első, második vagy harmadik helyen kerültek említésre. A szabad asszociációk a nagykanizsai idősek körében a következő megoszlást mutatják az egyes kategóriákban (2. ábra).

2. ábra: A szabad asszociációk megoszlása kategóriánként

Distribution of free associations by categories

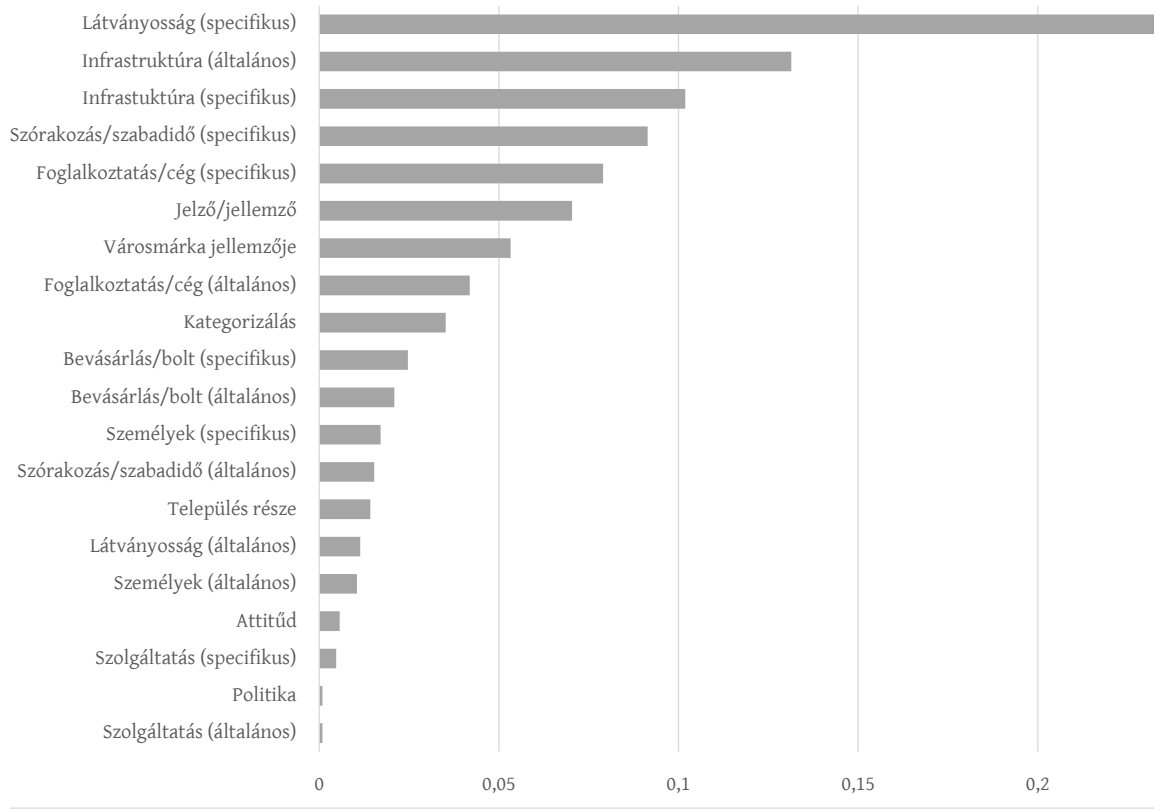

Forrás: Saját szerkesztés

Az adatokból egyértelműen látszik, hogy az idősek legtöbb esetben specifikus látványosságokat neveztek meg asszociációként. Mivel a célcsoport speciális igényekkel rendelkezik, érthető, hogy a megkérdezettek az általános infrastruktúra elemeit is kiemelték a szabad asszociáció során. Ebben megmutatkozik a biztonság, a kényelem, az egészségügyi ellátás és az utak, járdák állapotának fontossága. A szórakozással és szabadidővel összefüggő asszociációk - meglátásunk szerint - a minta összetételéből fakadnak, hiszen akik egy-egy idősklub aktív tagjai, feltehetően nyitott és aktív életet élnek.

A következő lépésben összeadtuk az általános és a specifikus asszociációkat az egyes kategóriákban. Az összesítés eredménye látható alább, a fó kategóriák szerint (3. ábra). 
3. ábra: A szabad asszociációk megoszlása az általános és a specifikus kategóriák összevonása után Distribution of free associations after the merging of general / specific categories

$30,0 \%$

$20,0 \%$

$15,0 \%$

$10,0 \%$

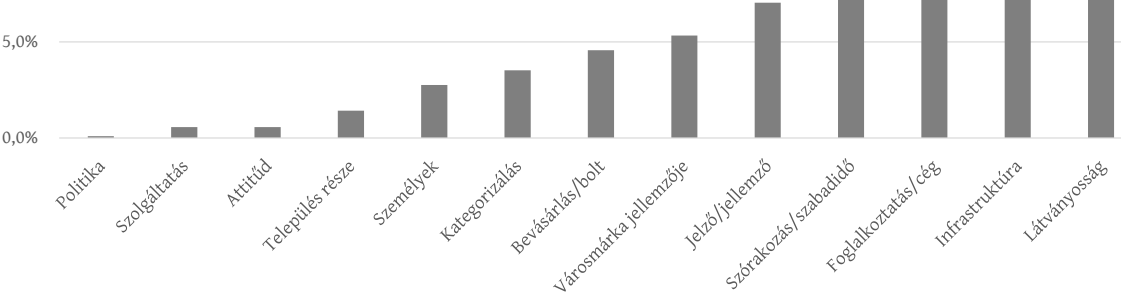

Forrás: Saját szerkesztés

Az összesítés alapján a látványosságokra és az infrastruktúrára vonatkozik a legtöbb említés. A harmadik legtöbb asszociációt tartalmazó kategória a foglalkoztatással, illetve a cégekkel kapcsolatos. A leggyakoribb szabad asszociációkat a 2. táblázat tartalmazza.

Az Erzsébet tér és a Csónakázó-tó asszociációkat a specifikus látványosságok közé soroltuk. Nagykanizsa főtere az Erzsébet tér, amelyet 2012-ben, a városrehabilitációs program keretében újítottak fel. A beruházás a tér funkcióit is átalakította: igazi találkozási, szórakozási és rendezvényközponttá vált, közösségi térként is funkcionál. A tér közvetlen környezetében számos vendéglátóegység müködik.

A Csónakázó-tó a város 1972-ben kialakított mestersége tava, a helyi lakosok kedvelt pihenőterülete, ahol horgászatra, csónak, vízibicikli és kerékpár bérlésére van lehetőség. (A tóban tilos fürdeni.) A tó a város fö rekreációs tere, zöld központja, a jelenlegi városfejlesztési törekvések egyik fó célterülete.

2. táblázat: A leggyakoribb szabad asszociációk

The most frequent free associations

\begin{tabular}{lc}
\multicolumn{1}{c}{ Asszociáció } & Említések száma \\
\hline Erzsébet tér & 138 \\
Csónakázó-tó & 42 \\
Kanizsai Bor- és Dödölle Fesztivál & 34 \\
\hline
\end{tabular}

Forrás: Saját szerkesztés 
A Kanizsai Bor- és Dödölle Fesztivál Nagykanizsa fő turisztikai rendezvénye: 2019-ben 20. alkalommal rendezték meg. A hagyományos zalai népi ételt, a dödöllét népszerűsítő fesztiválon kulturális programmal és széles gasztronómiai kínálattal várják a látogatókat. A rendezvény egyik fö célcsoportját az idősek jelentik.

Érdemes külön pillantást vetni a foglalkoztatással, cégekkel kapcsolatos asszociációkra is, amelyek azonban kevésbé pozitívak: nem a jelen teljesítményeire vonatkoznak, hanem a város iparának múltját és egykori jelentőségét emelik ki. A legtöbb (22), e kategóriába tartozó asszociáció a Kanizsai Sörgyárat említi. Az 1892 és 1999 között működő Kanizsai Sörgyár népszerü sörei (Balatoni Világos, Kinizsi) mellett Fonyódi ásványvizet és Gyöngy üdítőitalokat is palackozott. A sörgyárat (azaz a Dreher Sörgyárak Rt. nagykanizsai üzemét) bezárását követöen, 2003-ban a francia Malterie Soufflet Magyarország Kft. malátagyártó vállalat vette meg, és 2011 végéig malátagyárként működtette. Ezt követően többször felmerült a sörgyár újraindításának ötlete, ám eddig nem történtek konkrét lépések az ügyben (ZAOL 2015).

További, gyakori asszociációként jelenik meg a kategóriában a „nincs munkalehetőség / munkanélküliség” (20 említés), emellett többféle kontextusban is előkerülnek a szocializmus ideje alatt a megkérdezettek nagy része számára foglalkoztatást nyújtó, ám mára megszűnt, illetve külföldi kézbe került, és más név alatt müködő kanizsai gyárak: a sörgyár mellett az üveggyár, a bútorgyár, illetve a Dunántúli Kőolajipari Gépgyár (DKG).

A szabad asszociációk alapján kapott kép tehát kettős: tartalmazza a mai várost kedvelt látnivalóival és rendezett(ebb) városképével, de az idős generáció egyidejűleg a negatív változásokat - a gyárak megszűnését, munkalehetőségek hiányát - is hangsúlyos helyen említi.

\section{Irányított asszociációk - büszke}

Az első irányított asszociáció arra kérdezett rá, hogy a válaszadók mire büszkék Nagykanizsával kapcsolatban („Kérjük, soroljon fel három dolgot, amelyre büszke Nagykanizsán!"). A válaszokat szintén kategorizáltuk, az asszociációk ismeretében itt más kategóriákat is alkottunk, ugyanis nagyobb számban hívtak elő olyan asszociációkat, amelyek a szabad asszociációban nem, vagy csak egy-két esetben fordultak elő (4. ábra).

Jól látható, hogy a helyi idős lakosok a város jelenlegi képére, a látnivalókra és az infrastruktúrára a legbüszkébbek. Emellett - kisebb súllyal - megjelennek a különböző rendezvények, az oktatás és az üzletek. Az egyedi, specifikus látványosságok azonosíthatnak egy települést, amitől a város különleges lehet. Itt már kevésbé jelennek meg az ipari múlttal (illetve általában a múlttal) kapcsolatos asszociációk, annak ellenére, hogy a városban számos emlék utal a kereskedelem és a gazdaság fénykorára, az oktatási hagyományokra. Nagykanizsán jelentős tradíciója van néhány iparágnak, több nagy múltú cégről (pl. Dunántúli Kőolajipari 
4. ábra: Az irányított asszociációk megoszlása a „Kérjük, soroljon fel három dolgot, amelyre büszke Nagykanizsán!" kérdésre adott válaszok alapján Distribution of directed associations to the question „Please list three things you are proud of in Nagykanizsa!"

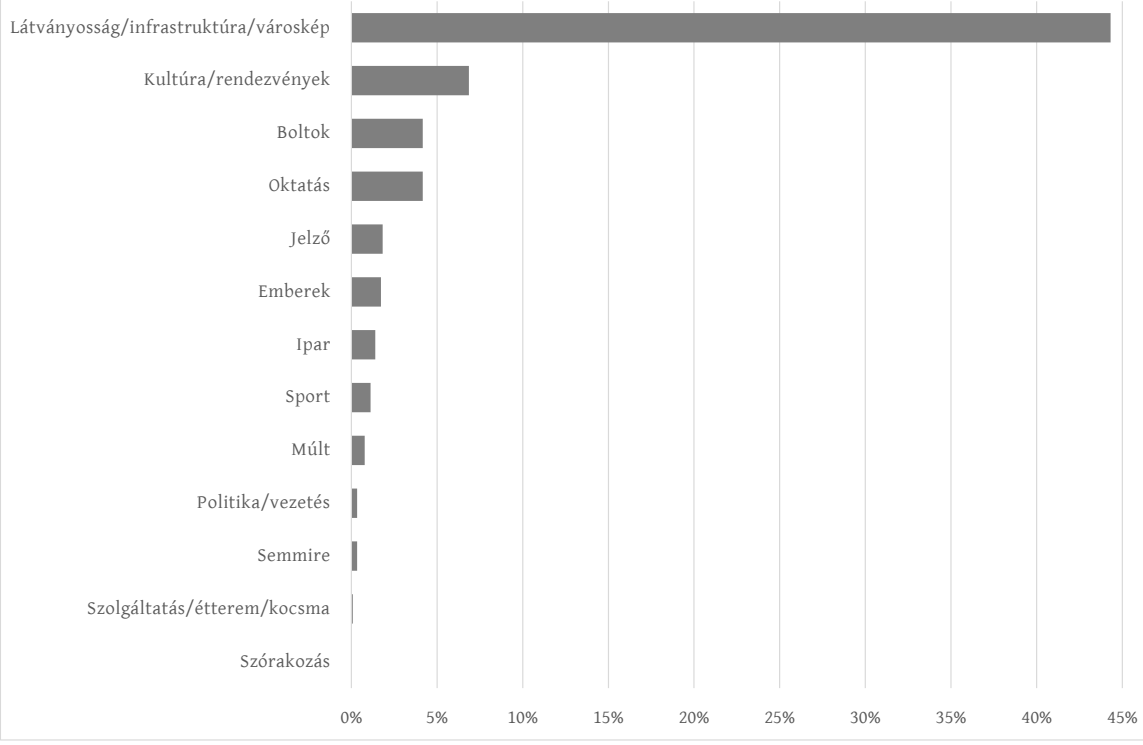

Forrás: Saját szerkesztés

Gépgyár, üveggyár, bútorgyár, sörgyár) beszélhetünk. Az infrastruktúrával kapcsolatos, büszkeségre okot adó asszociációk többsége a fentebb említett Erzsébet térre, a Csónakázó-tóra, illetve a Fő útra vonatkozik. Ezek az erős, büszkeséggel kapcsolatos asszociációk azért jöhettek létre, mert a város e látnivalói az elmúlt években megújultak.

\section{Irányított asszociációk - elégedett vs. elégedetlen}

A következő két kérdésben azt vizsgáltuk, hogy mivel elégedettek, illetve elégedetlenek az idős lakosok. Az előző (mire büszke?), és az elégedettségre utaló kérdés nem azonosak: elképzelhető, hogy büszke vagyok a városképre, ugyanakkor elégedetlen is vagyok, mert úgy gondolom - más városok példája alapján -, hogy az még szebb, vagy éppen modernebb is lehetne. A két feltett kérdés („Kérjük, írja le, hogy mivel elégedett Nagykanizsán! Kérjük, fogalmazza meg, hogy mivel nem elégedett Nagykanizsán!") nem kifejezetten asszociációkat kér, ugyanakkor projektív technika, amelyre a válaszadók rövid, pár szavas válaszokat adtak, vagyis a kérdés asszociációs folyamatokat indított el. Itt már az adatfeldolgozás első részében kategorizáltuk a válaszokat. A két kérdés kiegészíti egymást, ezért az eredményeket együtt vizsgáljuk (5. ábra). 
5. ábra: Az irányított asszociációk megoszlása a „Mivel elégedett?”, illetve „Mivel elégedetlen?” kérdésekre adott válaszok alapján

The distribution of directed associations to the question

"What are you satisfied or dissatisfied with in Nagykanizsa"?

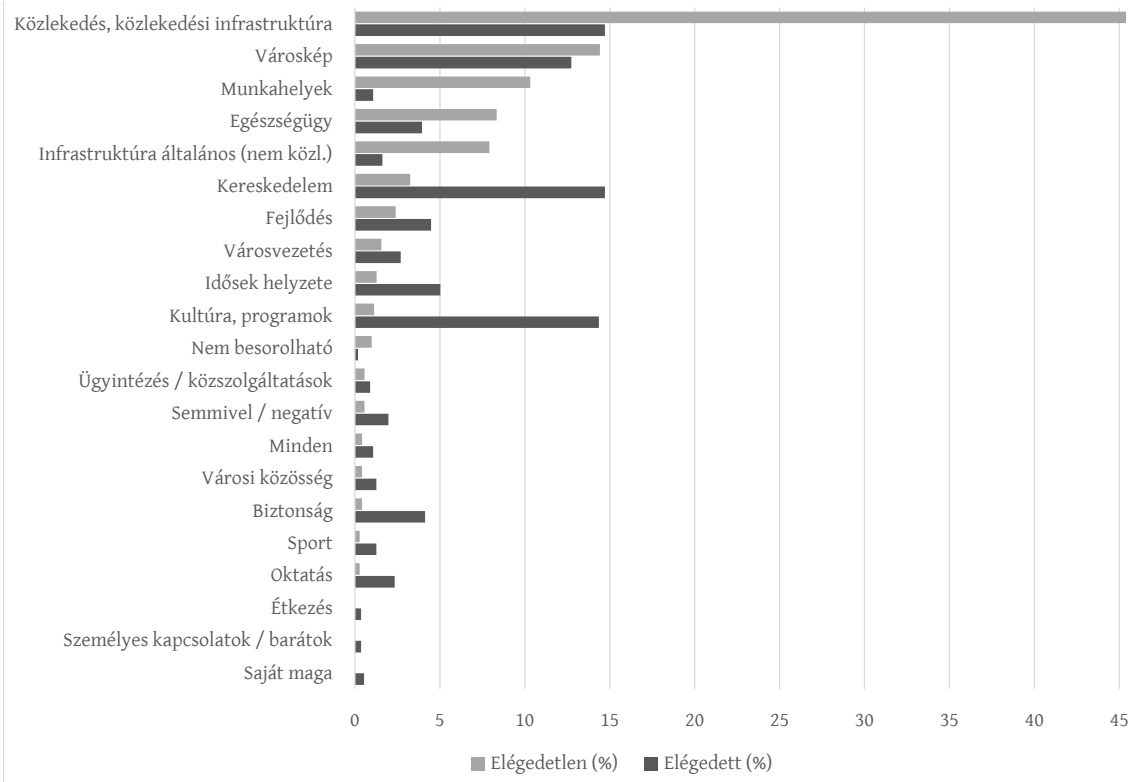

Forrás: Saját szerkesztés

Az ábrán jól látható, hogy a válaszadók között - kevés kivételtől eltekintve - ugyanazon jellemzők adnak okot az elégedettségre és az elégedetlenségre. Legszembetűnőbb a közlekedési infrastruktúra megítélése: közel háromszor gyakrabban jelenik meg a közlekedés negatív élményként, mint ahányszor elégedettek vele a válaszadók. Az asszociációkat egyenként vizsgálva az is látszik, hogy míg a helyi (busz)közlekedést inkább pozitívan ítélik meg a válaszadók, addig az utak állapotát negatívan. A leggyakoribb válaszokat a mivel elégedett / mivel elégedetlen kérdésekre a 3. táblázat tartalmazza.

Jól látható, hogy míg egyes kategóriák megosztottak (egyesek elégedettek, mások elégedetlenek), addig más kategóriák megítélése egységesebb: a városban a kultúra, a programok, illetve a biztonság a legtöbb válaszadó számára elégedettségre ad okot. Szintén elégedettek az idősek a saját helyzetükkel, valamint a kínált programokkal.

Egyes válaszok kettős természete (a válaszadók megosztottsága) abból is ered, hogy a városban a megnevezett ,javak” elosztása nem egyenletes: míg a helyi közlekedés a többségnek megfelel, addig azoknak, akik kevésbé frekventált helyeken közlekednek, a közlekedés nem megfelelő. Ez a válaszokból is egyértelmüen látszik: a buszközlekedés negatív megítélésére a válaszadók részben konkrét példákat (időpontokat, helyeket, járatszámokat) hoztak. 
3. táblázat: A leggyakoribb válaszok a mivel elégedett / mivel elégedetlen kérdésekre The most frequent associations respondents are satisfied or dissatisfied with in Nagykanizsa

\begin{tabular}{|c|c|c|c|}
\hline $\begin{array}{c}\text { Mivel elégedett? } \\
\text { A } 3 \text { leggyakoribb kategória }\end{array}$ & $\begin{array}{c}\text { Válaszok } \\
\text { száma }\end{array}$ & $\begin{array}{c}\text { Mivel elégedetlen? } \\
\text { A } 3 \text { leggyakoribb kategória }\end{array}$ & $\begin{array}{c}\text { Válaszok } \\
\text { száma }\end{array}$ \\
\hline $\begin{array}{l}\text { A buszok közlekedése, tömeg- } \\
\text { közlekedés (pl. helyközi közle- } \\
\text { kedés / helyijáratos közlekedés, } \\
\text { menetrend) }\end{array}$ & 50 & $\begin{array}{l}\text { Az (köz)utak, járdák állapota, } \\
\text { minősége (pl. rosszak, töredezet- } \\
\text { tek, sok a kátyú, nehéz a közleke- } \\
\text { dés, elesik az ember) }\end{array}$ & 195 \\
\hline $\begin{array}{l}\text { Kereskedelmi ellátás } \\
\text { (pl. élelmiszer-ellátás / jó bolti } \\
\text { ellátottság / sok nagy áruház / } \\
\text { bevásárolóközpont) }\end{array}$ & 37 & $\begin{array}{l}\text { Munkahelyhiány (pl. a fiatalok } \\
\text { kivándorolnak külföldre. munka- } \\
\text { helyteremtés. kevés új munka- } \\
\text { hely létesül) }\end{array}$ & 56 \\
\hline Vásárcsarnok, piac & 27 & $\begin{array}{l}\text { Autóbusz-közlekedés / városi } \\
\text { közlekedés szervezése (pl. busz- } \\
\text { közlekedés nem eléggé sűrű / } \\
\text { helyi autóbuszok menetrendje / } \\
\text { hétvégi autóbusz közlekedés) }\end{array}$ & 36 \\
\hline
\end{tabular}

Forrás: Saját szerkesztés

A megkérdezettek kifejezetten elégedetlenek egyrészt az általános - nem közlekedési - infrastruktúrával (pl. szelektív hulladékgyűjités, termálfürdő hiánya), valamint a városi munkalehetőségekkel. Ez utóbbi - többek között - az alábbi megfogalmazásokban jelenik meg: ,az ifjúság munkalehetősége nincs megoldva”, „kevés a fiatalokat megtartó munkalehetőség”.

Az adatok - nem meglepő módon - egészében azt mutatják, hogy az idősek azon jellemzőkkel elégedettek, amelyek megkönnyítik, illetve azokkal elégedetlenek, amelyek nehezebbé teszik az életüket. Ez alól kivételt képeznek a munkahelyhiánnyal kapcsolatos, többnyire az elégedetlen kategóriában említett összefüggések. A munkaerőhiány az idős lakosságot már nem közvetlenül, hanem közvetve érinti: feltételezhetően gyerekeik, illetve unokáik munkaerőpiaci lehetőségeit látva fogalmazzák meg észrevételeiket.

\section{Diszkusszió}

Ahogy korábban Zenker és Braun modellje alapján rámutattunk, egy városmárka által a tudatunkban előhívott asszociációs kapcsolatok célcsoportspecifikus jellemzőket mutatnak. A gyüjtött asszociációk elemzése alapján a következőkben Zenker és Braun (2017) modelljét alkalmazzuk a vizsgált célcsoportra (6. ábra).

Zenker és Braun modelljének a település kommunikációjáról szóló egységébe a szájpropaganda helyett a tapasztalatot vettük fel. Ennek oka, hogy a helyi lakosok nem szájpropagandából értesülnek a település egyes állandó vagy változó jellemzőiről, hanem hosszabb időn keresztül meg is élik azokat. Ezek a tapasztala- 
6. ábra: Zenker és Braun modelljének célcsoportspecifikus alkalmazása

Nagykanizsa város idős lakosainak asszociációira

Target group specific modification of the Zenker and Braun model based on the association of elderly residents of Nagykanizsa

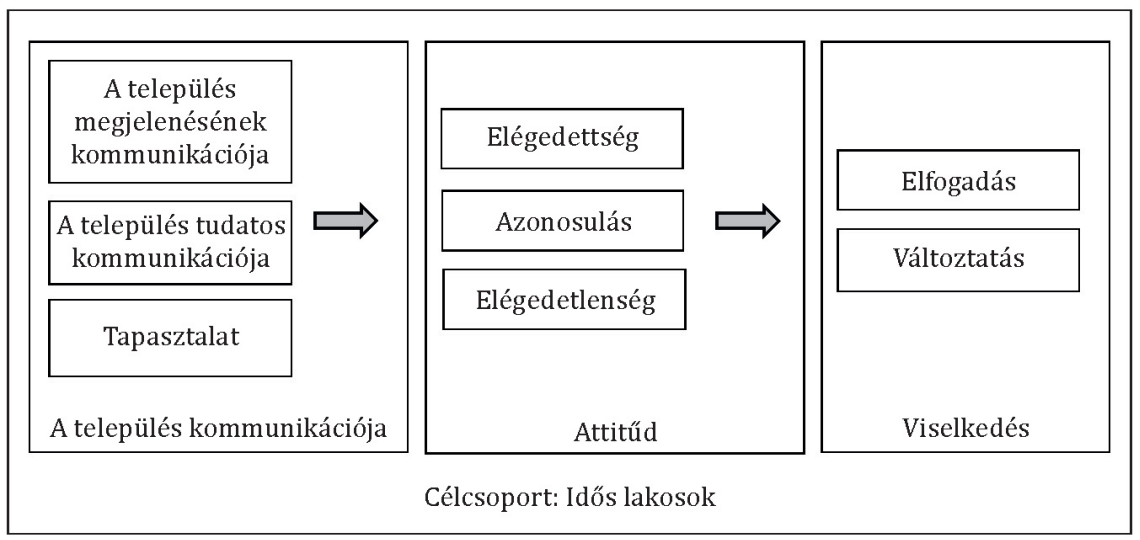

Forrás: Zenker, Braun $(2017,277$.$) alapján saját szerkesztés$

tok természetesen kiegészülnek mások tapasztalataival is, de fontos megjegyeznünk, hogy mások tapasztalata nem azonos asszociációs kapcsolatokat eredményez, mint a saját tapasztalataink. Olson, Fazio és Han (2009) rámutatnak arra, hogy azok az asszociációink, amelyek másoktól származnak, és mások attitűdjére utalnak, nem azonos súllyal rögzülnek mentális hálózatunkban saját attitűdjeinkként, így nem feltétlenül vannak hatással a döntéseinkre (Kovács 2017).

Az elégedettséget mint jellemzőt megtartottuk, hiszen az elégedettség alapvetően meghatározza a lakosok városmárkaképét (Rößler 2019; Zenker et al. 2013). Fontosnak tartottuk azonban az elégedetlenséggel is kiegészíteni az attitüdöket. Az elégedettség pozitív kifejezés, de ellentéteként a nem elégedett (= nem negatív, de nem is pozitív) és az elégedetlen (= negatív) fogalmak is értelmezhetők. Az asszociációkból egyértelmüen láttuk, hogy az attitűd nem szükségszerüen csak pozitív lehet: a helyi lakosok - tapasztalataik alapján - a város egyes elemeivel elégedetlenek is lehetnek. Az elégedetlenség eredménye lehetne az elköltözés (Rößler 2019), ez azonban az idősek esetében kevésbé valószínűsíthető viselkedés.

Mivel az idősek esetében a lakóhelyhez való kötődés általában erős (Dúll 2009), az elköltözés pedig érzelmi, fizikai és anyagi okokból sem alternatíva, az egyik lehetséges viselkedés az elfogadás, miközben megpróbálják kiemelni a település pozitív oldalát. A másik alternatíva a változtatás lenne, amely esetükben legfeljebb szük lakókörnyezetükre vonatkozik, illetve arra, hogy a változ(tat)ás iránti igényeiknek hangot adnak a megfelelő fórumokon és helyzetekben.

A modell alapján a településmárkák kognitív szerkezetével kapcsolatban megfogalmazhatjuk, hogy a településmárkát - mint elmebeli asszociációk termékét - nehéz általánosságban meghatározni: a településmárka jelentése a befogadóban, a 
(potenciális) fogyasztóban jön létre. Ezt a jelentést a marketingkommunikációs eszközök csak részben befolyásolják: a fogyasztó saját és mások tapasztalatai, illetve élményei alapján maga hozza létre a márka jelentését (Kastens, Lux 2014; Kovács 2016). Ezen márka-jelentésalkotás márkakommunikációtól való függetlensége különösen jól látszik a vizsgált célcsoportban, ahol az asszociációk szinte kizárólag a személyes tapasztalatok eredményeként alakultak ki.

\section{Javaslatok}

Minden generáció más felfogással és elvárásokkal éli mindennapjait (Németh et al. 2019; Péter, Németh 2019). Nagykanizsa Megyei Jogú Város Önkormányzata egyik kiemelt feladatának tekintette - a hazai idősügyi stratégia célkitűzéseivel egybehangzóan - a helyi szintű „idősbarát” politika kialakítását. Az idősbarát politika megvalósításában különös hangsúlyt fektetett az idős lakossággal való együttműködésre, figyelemmel kísérte az időskorú emberek életkörülményeit, fontosnak tartotta az idősek aktivitásának megőrzését és a róluk való gondoskodást. A cél elérése érdekében, 2007-ben újra megalakították Nagykanizsa Megyei Jogú Város Önkormányzat Idősügyi Tanácsát (a továbbiakban: Idősügyi Tanács). Az Idősügyi Tanács egy olyan, az önkormányzat mellett működő konzultatív, véleményezo, javaslattevő testület szerepét vállalta fel, amelynek tagjai (az önkormányzat mellett) helyi civil és egyházi szervezetek, más tevékenységet folytató polgári társulások, idősklubok. A létrehozott Idősügyi Tanács működésétől a tagok olyan feladatok kidolgozását és javítását várták el, amelyek védik az időskorú polgárok érdekeit, pozitívan befolyásolják a helyi életkörülményeket, többirányú kommunikációs csatornaként működnek, részt vesznek a rendezvényeken, és a tapasztalatok alapján további javaslatokat készítenek elő. A felsoroltak teljes mértékben megegyeznek az ENSZ (1991) idős embereket érintő alapelveivel és a WHO (2002) öregedésről szóló madridi cselekvési tervével, amelyben prioritásként szerepel az aktív társadalmi tevékenységekben való részvétel, az időskori anyagi biztonság, az egyenlő szociális és egészségügyi ellátáshoz való hozzáférés, valamint az időskorú társadalmi csoportok jogainak védelme. A prioritásokat, célkitűzéseket leghatékonyabban a helyi önkormányzatok tudják megvalósítani, amelyek kezdeményezhetik szakmai testületek felállítását, konkrét feladatok és koncepciók kidolgozását. A feladatok megvalósítása lehet kötelező vagy önkéntes vállalás is.

A gerontológiai, illetve orvostudományi kutatások elsődlegesen az idősek életkorának kitolására fókuszálnak, holott Zsarnóczky $(2018,2019)$ több kutatása felhívja a figyelmet arra, hogy nem csupán az emberi élet hossza lehet meghatározó cél, hanem az élet minőségének és a pozitív értelemben vett jólét biztosítása is. Az idős korosztály számára például a biztonság fogalma nem elsődlegesen az anyagi jólétet, hanem az egészséget és az orvosi szolgáltatások elérhetőségét je- 
lentheti. Az idősek önmagukban is heterogén csoportot alkotnak (Gyulavári, Ásványi 2019). Az aktív idősek csoportja számára értéket képvisel például az, hogy önálló döntéseket hozhatnak. Az idős generáció a településre nézve erőforrást - tudásbázist, esetleg munkaerőt - is jelenthet. A következőkben a leírt összefüggések és eredmények alapján javaslatokat szeretnénk megfogalmazni arra vonatkozóan, hogy a város milyen intézkedéseket valósíthat meg, amelyek nemcsak megkönnyítik az idősek helyzetét, hanem az általuk képviselt (tudás)potenciál hasznosításához is hozzájárulhatnak.

\section{A város élhetöségének javitása}

Az idősek számára fontos az élhető lakókörnyezet. Ez egyrészt a mindennapi megélhetés biztosítását jelenti, például a kereskedelmi és más szolgáltatások viszonylag könnyű megközelíthetőségét, másrészt a különböző egészségügyi szolgáltatásokhoz való hozzáférést. A szabad asszociációk esetében láttuk, hogy a megkérdezettek az általános infrastruktúra azon elemeit emelték ki, amelyek a biztonságukat, kényelmüket és egészségüket szolgálják. Az élhetőséget javítaná olyan újabb rekreációs parkok létrehozása, ahol sétálni lehet, és a megfelelö infrastruktúra - kényelmes padok, mosdó - is rendelkezésre áll. A válaszadók a büszkeségre vonatkozó kérdésnél olyan helyszíneket (a város fötere, föutcája, fö rekreációs területe) neveztek meg, amelyek arra utalnak, hogy szívesen töltik ott a szabadidejüket, és valószínűleg örömmel látnának újabbakat, illetve örömmel vennék, ha a már kialakított helyszíneken nyilvános mosdó is hozzáférhető lenne. Hasznos lehet olyan önkéntes programok indítása, ahol fiatalok segítik az idöseket a bevásárlásban, takarításban, közösen sétálnak, vagy csak beszélgetnek. Ennek megszervezése jelenleg hiányzik városi szinten, csak az iskolásoknak kötelező közszolgálati program részeként jelenik meg, például az Idősek Otthonában.

\section{A mobilitás biztosítása}

A válaszadók közül 195-en voltak elégedetlenek a (köz)utak, járdák állapotával (rosszak, töredezettek, sok a kátyú, nehéz a közlekedés, elesik az ember). Fontos lenne a biztonságos gyalogos közlekedés biztosítása, például a gyalogátkelőhelyek biztonságának erősítésével (lámpa felszerelése, zöld jelzés időtartamának növelése), és - ahol szükséges - a járdák felújításával. Sokatmondó eredmény, hogy háromszor többen voltak elégedetlenek a közlekedéssel, mint ahányan elégedettnek mondták magukat. Példamutató kezdeményezés a Jézus Szíve katolikus plébánia karácsonyi ingyenes buszjárata a sürün lakott keleti városrész és a templom között, ami szenteste az éjféli misére szállítja az időseket. Sok idős jár Zalakarosra, így megfontolandó alacsony padlós buszjáratok indítása, melyek a városban több helyen is megállhatnának. 


\section{Az idősek mint tudásbázis és oktatási célcsoport}

Az asszociációk alapján is látszik, hogy nagy számban rendeznek a városban időseknek (is) szóló rendezvényeket, és kutatásunk eredményei azt mutatják, hogy a válaszadók ezekkel elégedettek. Hiányoznak azonban azok a rendezvények, amelyek az idősek tudására alapozva erősítenék a város identitását. A kutatásból kiderült, hogy a helyi idősklubok tagjai aktívak, nyitottak, így érdemes lenne bevonni őket a rendezvények szervezésébe is. Programjavaslatok:

- Kiállítás és programsorozat „az én Kanizsám” címmel, ahol az idősek elmesélik, illetve személyes élményekkel és tárgyakkal bemutatják az ő Nagykanizsájukat.

- Előadássorozat „Amikor az okostelefon még tervben sem volt - hogyan teltek a mindennapok a múlt században?" címmel, amely sorozat az előző évszázad mindennapi életét eleveníti fel (pl. a munka és szórakozás, a játékok területén). Ezen programok akár a Múzeumok éjszakája programsorozat részei lehetnének.

Hasznos lehetne továbbá a több városban már működő Nyugdíjas Egyetem elindítása, melynek keretében oklevelet kapnának azok az idősek, akik végigülik az előadásokat (öt-hat alkalom / szemeszter), és elvégzik a kiadott feladatokat.

\section{Összefoglalás}

Kutatásunkban a Nagykanizsán élő idős népesség várossal kapcsolatos asszociációit elemeztük. Az asszociációk által kirajzolt városkép rámutat arra, hogy mi nehezíti vagy könnyíti meg az idősek mindennapjait. Emellett a város múltja is megjelenik az asszociációs struktúrákban: az idős generáció élénken emlékszik - és valószínűleg nosztalgiával és büszkeséggel gondol vissza - a város egykori ipari potenciáljára, a korábban országos hírű gyárakra. Fontos kiemelnünk azonban, hogy az idős generációt nem csak saját mikrovilágának történései, illetve a múlt foglalkoztatják: a város és a fiatal generációk jövőjét is fontosnak tartják, elsősorban a megfelelő mennyiségü és minőségű munkahely biztosítását tartják szükségesnek.

A városmárkához kapcsolódó asszociációs struktúrák elemzése során elméleti modellek igazolására is vállalkoztunk: Zenker és Braun (2017) modelljének módosításával rámutattunk arra, hogy egy adott célcsoport esetében a modell minden összetevője bővíthető a vizsgált célcsoporttól gyűjtött empirikus adatok alapján. A tanulmány végén megfogalmaztunk néhány javaslatot, amelyek hozzájárulhatnak ahhoz, hogy a város idős lakosságát jobban lehessen integrálni a település mindennapjaiba, és hogy az általuk képviselt tudás és tapasztalat a következő generációk számára is hozzáférhető legyen. 
Tanulmányunk egyik korlátja, hogy csak egy város lakosainak asszociációit vizsgáltuk: így a kutatás jelenlegi szakaszában nem mondható meg, hogy az eredmények mely része városspecifikus (azaz kifejezetten Nagykanizsára vonatkozó, lásd Kovács et al. 2020), és mely része korosztályspecifikus (azaz mennyire jellemző általánosan a városok időskorú lakosaira). A korosztályspecifikus jellemzők egyértelműen megjelennek az asszociációs struktúrákban, ha az adatokat egy másik korcsoport, a középiskolások asszociációival is összehasonlítjuk (Kovács et al. 2020). A következő lépés így a különböző korosztályok asszociációs struktúráinak összevetése, az átfedések és különbségek megállapítása, majd ezek alapján egy általánosabb, empirikus adatokkal alátámasztott modell megalkotása, melyet más városok adataira is alkalmazhatunk.

Ahhoz, hogy ezt a kérdést megvizsgáljuk, további kutatásokat tervezünk más városok - elsősorban Szombathely - bevonásával. Az adatgyüjtés során részben módosított - adott városra adaptált - kérdőívvel dolgozunk, majd a gyüjtött adatokat összevetve elemezni kívánjuk a városspecifikus és a korosztályspecifikus asszociációkat. A kutatás további szakaszai azonban a 2020 tavaszán kialakult járványügyi helyzet miatt sajnos időben nem tervezhetők.

A kutatási eredmények rávilágítanak arra, hogy a városmárkával összefüggő asszociációk vizsgálata - új megközelítésként - nemcsak a városmárka építésében, valamint a város külső és belső kommunikációs stratégiájának tervezésében kaphat kiemelt szerepet, de korcsoportspecifikus városmenedzsment-stratégiák alapjául is szolgálhat.

\section{Irodalom}

Aaker, D. A. (1991): Managing Brand Equity. Free Press, New York, NY

Aaker, D. A., Kumar, V., Day, G. S. (2001): Marketing research. 7th ed., John Wiley \& Sons, Hoboken Bauer A., Berács F. (2006): Marketing. Aula Kiadó, Budapest

Birkner Z. (2017): Települési-térségi identitás. In: Berkesné Rodek N., Birkner Z., Ernszt I. (szerk.): Köldökzsinór. A Pannon Városok Szövetségéhez tartozó városok sikerének és megtartóerejének kulcstényezői. Felsőbbfokú Tanulmányok Intézete, Kőszeg, 95-128.

Depping, M. K, Freund, A. M. (2011): Normal Aging and Decision Making: The Role of Motivation. Human Development, 54., 349-367. https://doi.org/10.1159/000334396

Dinnie, K. (2011): Introduction to the Theory of City Branding. In: Dinnie, K. (ed.): City Branding. Palgrave Macmillan, Houndmills, 3-7. https://doi.org/10.1057/9780230294790_1

Dörnyei K., Csordás T., Gáti M. (2013): A kommunikáció információs meghatározottsága: Információkeresés, -feldolgozás és -befogadás. In: Horváth D., Bauer A. (szerk.): Marketingkommunikáció. Stratégia, új média, fogyasztói részvétel. Akadémiai Kiadó, Budapest, 44-51.

Drolet, A., Schwarz, N., Yoon, C. (eds.) (2011): The Aging Consumer: Perspectives From Psychology and Economics. Routledge, New York, NY https://doi.org/10.4324/9780203852941

Dúll A. (2009): Helyek, tárgyak, viselkedés. Környezetpszichológiai tanulmányok. L'Harmattan, Budapest

Egresi, I. (2018): "Tourists go home!" - Tourism overcrowding and "tourismophobia" in European cities. In: [Co]habitation tactics. TAW2018 International Scientific Conference, Conference Proceedings, Tirana, 701-714. 
Franzen, G., Bouwman, M. (2001): The Mental World of Brands. World Advertising Research Centre, Henley-on-Thames

Gyulavári T., Ásványi K. (2019): Szeniorturizmus. In: Irimiás A., Jászberényi M., Michalkó G. (szerk.): A turisztikai termékek innovatív fejlesztése. Akadémiai Kiadó, Budapest

Gyulavári, T., Malota, E. (2019): The role of culture personality and self-congruity in the evaluation of cultures as destinations, Tourism Review, 3., 632-645. https://doi.org/10.1108/TR-02-20180026

Gyulavári T., Mitev Ariel Z., Neulinger Á., Neumann-Bódi E., Simon J., Szűcs K. (2014): A marketingkutatás alapjai. Akadémiai Kiadó, Budapest

Hanna, S., Rowley, J. (2015): Towards a model of the Place Brand Web. Tourism Management, 48., 100-112. https://doi.org/10.1016/j.tourman.2014.10.012

Hess, M. T., Strough, J., Löckenhoff, E. C. (eds.) (2015): Aging and Decision Making. Empirical and Applied Perspectives. Academic Press, Cambridge

Insch, A. (2011): Branding the City as an Attractive Place to Live. In: Dinnie, K. (ed.): City Branding. Palgrave Macmillan, Houndmills, 8-15. https://doi.org/10.1057/9780230294790_2

Kastens, I. E. (2008): Linguistische Markenführung. LIT, Münster

Kastens, I. E., Lux, P. G. C. (2014): Das Aushandlungs-Paradigma der Marke. Springer Gabler, Wiesbaden https://doi.org/10.1007/978-3-658-02196-2

Keller, K. L. (1998): Strategic Brand Management. Prentice Hall, New Jersey

Kotler, P., Haider, D.H., Rein, I. (1993): Marketing Places: Attracting Investment, Industry, and Tourism to Cities, States, and Nations. The Free Press, New York

Kovács, L. (2016): Marke im Kopf: ein kognitionslinguistischer Blick auf Markenbilder. In: Kastens, I. E., Busch, A. (Hg.): Handbuch Wirtschaftskommunikation. Narr Francke Attempto, Tübingen, 258-293.

Kovács L. (2017): Márka és márkanév. Tinta Kiadó, Budapest

Kovács L., Keller K., Tóth-Kaszás N., Knausz L. (2020): Nagykanizsa mint márka - középiskolások körében végzett városmárka-asszociációs vizsgálatok eredményei. Vezetéstudomány, 51/3., 17-29.

Malhotra, N. K., Simon J. (2007): Marketingkutatás. Akadémiai Kiadó, Budapest

Namaz, L., Horváth D. Cosovan A., Tvergyák K. K. (2018): Városmárka-hűség: melyek a budapesti márkahűséget befolyásoló legfőbb tényezők? Turizmus Bulletin, 4., 4-13.

Németh K., Czira T., Sütő A., Péter E., Domjánné Nyizsalovszki R. (2019): Félig tele vag félig üres? Turizmus szektort érintő klímaalkalmazkodási kérdések vizsgálata a Nyugat-Balatoni térségben. Comitatus: Önkormányzati Szemle, 232., 55-62.

Olson, M. A., Fazio, R. H., Han, H. A. (2009): Conceptualizing Personal and Extrapersonal Associations. Social and Personality Psychology Compass, 3., 152-170. https://doi.org/10.1111/j.1751-9004.2008.00164.x

Péter E., Németh K. (2019): A különböző generációk fogyasztói szokásainak elemzése a Dunántúli térségben, LXI. Georgikon Napok - Nemzetközi Tudományos Konferencia, Innovációs kihívások a XXI. században konferencia kiadvány, Keszthely, 323-332.

Piskóti I. (2012): Régió- és településmarketing. Akadémiai Kiadó, Budapest

Rekettye G., Hetesi E. (2009): Kínálatmenedzsment. Akadémiai Kiadó, Budapest

Rößler, A. (2019): Internal City Branding. Springer Gabler, Wiesbaden. https://doi.org/10.1007/978-3658-24588-7

Vanolo, A. (2017): City Branding. Routledge, New York, NY. https://doi.org/10.4324/9781315660660

Zenker, S. (2011): How to catch a city? The concept and measurement of place brands, Journal of Place Management and Development, 1., 40-52. https://doi.org/10.1108/17538331111117151

Zenker, S., Beckmann, S. C. (2013): My place is not your place - different place brand knowledge by different target groups. Journal of Place Management and Development, 1., 6-17. https://doi.org/ $10.1108 / 17538331311306078$

Zenker, S., Braun, E. (2010): Branding a city - a conceptual approach for place branding and place brand management. Proceedings of the 39th European Marketing Academy Conference, Copenhagen, 1-8.

Zenker, S., Braun, E. (2017): "Questioning a "one size fits all" city brand: Developing a branded house strategy for place brand management". Journal of Place Management and Development, 3., 270-287. https://doi.org/10.1108/JPMD-04-2016-0018 
Zenker, S., Braun, E., Petersen, S. (2017): Branding the destination versus the place: The effects of brand complexity and identification for residents and visitors. Tourism Management 58., 15-27. https://doi.org/10.1016/j.tourman.2016.10.008

Zenker, S., Petersen, S., Aholt, A. (2013): The Citizen Satisfaction Index (CSI): Evidence for a four basic factor model in a German sample. Cities, 31., 156-164. https://doi.org/10.1016/j.cities. 2012.02.006

Zsarnóczky, M. (2016): Innovation Challenges of the Silver Economy. Vadyba Journal of Management, 1. 105-109.

Zsarnóczky, M. (2017): Developing Senior Tourism in Europe. Pannon Management Review, 3-4., 201-214.

Zsarnóczky, M. (2018): Subjective life quality research among elderly people in one of the happiest Hungarian towns. Book of Papers of the Masterclass of 6th European Week of Regions and Cities, Brussels, 64-73.

Zsarnóczky M. (2019): A coaching és szociális munka kapcsolata az akadálymentes desztinációk tervezésében. In: Zsarnóczky M., Rátz T., Michalkó G. (szerk.): VII. Magyar Turizmusföldrajzi Szimpózium 2019, Kodolányi János Egyetem, Budapest, 104.

\section{Dokumentumok}

ENSZ [Egyesült Nemzetek Szervezete] (1991): Idős emberekkel foglalkozó alapelvei. Öregedésról szóló Bécsi Nemzetközi Cselekvési Terv Bécs

Idősügyi Tanács honlapja (2019): Idősügyi klubok, szervezetek http://nagykanizsa.60plus.hu/klubok.htm (Letöltés: 2019.09.15.)

M7 Projektcsoport Pannon Egyetem Nagykanizsa (2009): „Töviseken át a csillagokig” A Nagykanizsai Ipari Park es Logisztikai Központ kereslet- es kínálatelemzése, a már betelepült vállalkozások elégedettségének vizsgálata, ajánlások Nagykanizsa Megyei Jogú Város részére https://www.nagykanizsa.hu/ docs/koncepciostrategia/nkmjvstratterve.pdf (Letöltés: 2019.09.14.)

Nagykanizsa honlapja (2019): https://www.nagykanizsa.hu/ (Letöltés: 2019.09.14.)

Nagykanizsa Megyei Jogú Város Önkormányzatának Idösügyi Koncepciója (2012) http://nagykanizsa. 60plus.hu/dokumentum/idosugyi_koncepcio_2012_2015.pdf (Letöltés: 2019.09.15.)

Településstatisztikai adatok korcsoportonként (2019): https://www.nagykanizsa.hu/varos/statisztika (Letöltés: 2019.09.15.)

Városfejlesztés Zrt. (2014): Nagykanizsa Megyei Jogú Város Településfejlesztési Koncepciója, Integrált Településfejlesztési Stratégiája Budapest https://www.nagykanizsa.hu/docs/koncepciostrategia/ nkmjvits20140909.pdf (Letöltés: 2019.09.14.)

WHO (2002): Öregedésról szóló Madridi Nemzetközi Cselekvési Terv Madrid

ZAOL (2015): Múltidéző: Volt egyszer egy Kanizsai Sörgyár - Több, mint száz évig üzemelt az 1892-ben alapított dél-zalai társaság https://www.zaol.hu/kiegeszito-rovat/multidezo-volt-egyszer-egykanizsai-sorgyar-tobb-mintszaz-evig-uzemelt-az-1892-ben-alapitott-del-zalai-tarsasag17329 05/ (Letöltés: 2019.10.05.) 